\title{
Metabolism of Arginine, Citrulline, Ornithine and Proline by Starved Rumen Ciliate Protozoa
}

\author{
Ryoji Onodera, Yoshitsugu Yamaguchi and Shuji Morimoto \\ Laboratory of Animal Nutrition, Department of Animal Science, \\ Faculty of Agriculture, Miyazaki University, Miyazaki 880, Japan
}

Received September 30, 1982

\begin{abstract}
Studies were initiated to examine the formation of urea and/or ammonia from arginine and some other amino acids, and the metabolism of arginine, citrulline, ornithine, and proline in a starved rumen ciliate protozoal suspension. Not urea but ammonia was produced from arginine and also from citrulline, ornithine, aspargine and glutamine of the 10 amino acids tested. Urea was not hydrolysed. Using labeled compounds, citrulline was paper- and column-chromatographically identified as the first intermediate in arginine metabolism. Citrulline, ornithine and proline were converted to ornithine, proline and $\delta$-aminovalerate (DAV), respectively. DAV underwent no more degradation. The ability to reduce proline to DAV decreased with the incubation time for preparing the starved ciliate suspension. Appreciable amounts of arginine and arginine with citrulline were synthesized from citrulline and ornithine, respectively.
\end{abstract}

Van den Hende et al. ${ }^{1)}$ reported that the metabolites in arginine metabolism in mixed rumen bacteria included citrulline, ornithine, proline, $\delta$-aminovalerate (DAV), valerate and ammonia.

In a previous paper ${ }^{2}$ we described the production of ornithine as an intermediate in the first step of arginine metabolism in a washed rumen ciliate protozoal suspension based on the results of paper chromatography of the sample obtained after incubation with $\left[\mathrm{U}-{ }^{14} \mathrm{C}\right]-$ L-arginine. Urea, presumed to be a potential alternative metabolite, however, could not be actually identified in that experiment and instead a considerable amount of radioactive carbon dioxide was detected. In this regard, most investigators ${ }^{3 \sim 5)}$ ruled out the possibility of ureolytic activity of rumen ciliates at the time and then we also examined their ureolytic activity and reached the conclusion that rumen ciliates themselves did not have ureolytic activity, because prolongation of the incubation time for the ciliates in the buffer solution containing antibiotics rapidly reduced the activity, despite the fact that the initial washed ciliate suspension showed appreciable activity. ${ }^{6)}$ On the other hand, viable counts of mingled bacteria in the washed suspension of rumen ciliates decreased with prolongation of the incubation time in the presence of antibiotics and eventually reached zero. ${ }^{7)}$ Thus the initial ureolytic activity of the washed ciliate suspension $^{6)}$ was attributed to the mingled rumen bacteria in the suspension. ${ }^{7)}$ Production of radioactive carbon dioxide in the washed ciliate suspension, ${ }^{1)}$ therefore, was also attributed to the hydrolysis of radioactive urea by the mingled bacteria in the ciliate suspension. ${ }^{6}$ )

The present paper describes an attempt at the formation of urea and ammonia from some amino acids and further studies of the metabolism of arginine and related compounds by the starved rumen ciliate suspension.

\section{MATERIALS AND METHODS}

1. Preparation of starved rumen ciliate protozoa. Rumen ciliates were obtained just before daytime feeding as described in the previous paper, ${ }^{8)}$ from a fistulated goat (Japanese-Saanen, female, $45 \mathrm{~kg}$ ) given 3 to $5 \mathrm{~kg}$ of green native grasses in the daytime and a ration consisting of $300 \mathrm{~g}$ of starch pulp and $200 \mathrm{~g}$ of mixed concentrate feed in the evening. Then the ciliates (washed ciliates) were suspended so as to be about $4 \%(\mathrm{v} / \mathrm{v})$ in concentration in 
MB9 buffer solution ${ }^{9)}$ containing $100 \mu \mathrm{g} / \mathrm{ml}$ each of dihydrostreptomycin sulfate, penicillin $\mathrm{G}$ potassium and chloramphenicol sodium succinate, and incubated at $39^{\circ} \mathrm{C}$ for 12 or $24 \mathrm{hr}$. When starved for $24 \mathrm{hr}$, at the middle of the incubation period the same amount of each antibiotic was added again. After incubation, the ciliates were washed five times with warmed MB9. The ciliates thus obtained were shown to be free from anaerobically viable bacteria ${ }^{7)}$ and are referred to as 'starved ciliates' in this paper. The fauna found in the present experiments consisted of Entodinium, Diplodinium, Dasytricha and Isotricha. The ciliate suspension was always used at about $4 \%(\mathrm{v} / \mathrm{v})$ concentration in MB9 containing $100 \mu \mathrm{g} / \mathrm{ml}$ each of the three kinds of antibiotics described above.

\section{Incubation procedure and sample treatments}

a) Experiment to examine the formation of urea and ammonia. Ten-ml portions of a starved $(24 \mathrm{hr})$ ciliate suspension were incubated with or without 10 individual amino acids $(10 \mu \mathrm{mol} / \mathrm{ml})$ or urea $(10 \mu \mathrm{mol} / \mathrm{ml})$ at $39^{\circ} \mathrm{C}$ for $6 \mathrm{hr}$ in $30-\mathrm{ml}$ conical flasks. After incubation, $0.2-\mathrm{ml}$ portions of the incubation medium were used to estimate the concentrations of ammonia and urea.

b) Experiment to examine the metabolism of non-labeled arginine, citrulline and ornithine. Twenty-ml portions of a starved $(12 \mathrm{hr})$ ciliate suspension were incubated with or without L-arginine $(3 \mu \mathrm{mol} / \mathrm{ml})$, L-citrulline $(1 \mu \mathrm{mol} / \mathrm{ml})$ or L-ornithine $(3 \mu \mathrm{mol} / \mathrm{ml})$ at $39^{\circ} \mathrm{C}$ up to $12 \mathrm{hr}$. After incubation for 0,6 or $12 \mathrm{hr}$, a $5-\mathrm{ml}$ portion of the incubation medium was withdrawn with stirring, mixed with $1 \mathrm{ml}$ of $60 \%$ trichloroacetic acid (TCA) and left overnight in a cold room $\left(4^{\circ} \mathrm{C}\right)$ to deproteinize. Then the mixture was centrifuged at $3000 \times g$ for $5 \mathrm{~min}$ to collect the supernatant fluid. A portion of the fluid was washed three times with ethyl ether to remove TCA and used for amino acid analysis.

c) Experiments with radioactive amino acids. Four-ml portions of a starved $(12 \mathrm{hr}$ ) ciliate suspension (or a washed ciliate suspension, when necessary) were incubated with given amounts of radioactive and non-radioactive Larginine, L-ornithine or L-proline and as occasion demanded, together with a different amino acid or urea (see text and Tables II to V) at $39^{\circ} \mathrm{C}$ for a given time (see Tables) in Warburg flasks with center wells to which $0.7 \mathrm{ml}$ of $20 \%$ $\mathrm{KOH}$ was added previously to trap carbon dioxide. Before incubation, a portion $(5 \mu \mathrm{l})$ of the medium in each flask was takẻn out to estimate the initial radioactivity. After incubation, $1 \mathrm{ml}$ of $50 \% \mathrm{TCA}$ was rapidly poured into the main chamber of the Warburg flask and the flask was left overnight to stop the microbial activity, release carbon dioxide from the medium and trap it in the $20 \% \mathrm{KOH}$. The $\mathrm{KOH}$ solution was transferred to a graduated test tube and made up to $10 \mathrm{ml}$ with water. A portion was assayed for radioactivity. Incubation medium in the main chamber was centrifuged at $3000 \times g$ for $5 \mathrm{~min}$ to separate supernatant fluid and precipitate (chiefly ciliates). The precipitate was washed five times with $10 \%$ TCA by centrifugation as described above and hydrolysed in $6 \mathrm{~N}$ $\mathrm{HCl}$ at $110^{\circ} \mathrm{C}$ for $20 \mathrm{hr}$ in an oxygen-free oval-type flask with a cock. The hydrolysate was filtered and a portion of the filtrate was assayed for radioactivity. The supernatant fluid also containing the washings of the precipitate was washed three times with ethyl ether to remove TCA and other ether-soluble substances. The ether fraction was mixed with about $50 \mathrm{ml}$ of water, neutralized with $40 \%$ $\mathrm{NaOH}$, using phenolphthalein as an indicator, and concentrated, and then a portion was assayed for radioactivity. The water-soluble fraction was evaporated to dryness at $60^{\circ} \mathrm{C}$ on a rotary evaporator and re-dissolved in $10 \mathrm{ml}$ of water. A $5-\mathrm{ml}$ portion was taken out, dried and redissolved in $0.5 \mathrm{ml}$ of citrate buffer solution $(\mathrm{pH} \mathrm{2.2,} \mathrm{for}$ amino acid analysis). A portion was used for amino acid analysis. The remaining portion $(5 \mathrm{ml})$ of the water-soluble fraction was desalted using 'Amberlite' CG-120 as described before ${ }^{2)}$ and used for paper chromatography.

In the experiment on proline metabolism, a rumen bacterial suspension, which was prepared as a $10^{-1} \mathrm{di}-$ lution of the first washings of freshly obtained ciliates with MB9, was also used for incubation with or without the three kinds of antibiotics mentioned above. The incubation procedure and sample treatments were similar to those for the ciliate suspension.

3. Analytical methods. Amino acids were assayed with an amino acid autoanalyzer (Model: AA-100, Sibata Chemical App. Mfg. Co., Ltd., Japan) using a 100-cm column at $56^{\circ} \mathrm{C}$ for usual amino acids including DAV and at $32^{\circ} \mathrm{C}$ for citrulline. Radioactive amono acids were similarly assayed with the analyzer and the eluate (reaction mixture with ninhydrin) of the amino acid peak in question was completely collected, mixed with a few drops of octyl alcohol and bubbled with air for $5 \mathrm{~min}$ to remove radioactive carbon dioxide which had been released by the ninhydrin reaction. A portion of the eluate was assayed for radioactivity. The true radioactivity of the amino acid fraction was calculated from the value determined by taking account of the released radioactive carbon dioxide according to Van Slyke et al. ${ }^{10)}$

Radioactivity was determined with a liquid scintillation spectrometer (LSC-903, Aloka Co., Ltd., Japan) using the scintillator as described before. ${ }^{2)}$

Two-dimensional paper chromatograms were obtained with solvents (1) $n$-BuOH-Pyridine- $\mathrm{H}_{2} \mathrm{O}(1: 1: 1)$ (referred to as BuP) and (2) Phenol-EtOH- $\mathrm{H}_{2} \mathrm{O}$ conc.aq. $\mathrm{NH}_{3}(120: 40: 40: 1)$ (referred to as PhEtAm), in that order, and autoradiography of the paper chromatogram was carried out by the method described before. ${ }^{2)}$

Ammonia and urea were determined by the microdiffusion method of Conway. ${ }^{11)}$ Nitrogen was determined by the micro-Kjeldahl method.

Counting of the ciliates was carried out by the method described in the previous paper ${ }^{7)}$ using a Fuchs-Rosenthal hemacytometer. 
4. Chemicals. All amino acids and urea were supplied by Wako Pure Chemical Industries, Ltd. Dihydrostreptomycin sulfate, penicillin $G$ potassium and chloramphenicol sodium succinate were supplied by Meiji Seika Kaisha, Ltd., Banyu Pharmaceutical Co., Ltd., and Sankyo Co., Ltd., respectively.

[U- $\left.{ }^{14} \mathrm{C}\right]-\mathrm{L}-$ Arginine $(351 \mathrm{mCi} / \mathrm{mmol}), \quad\left[\mathrm{U}-{ }^{14} \mathrm{C}\right]-\mathrm{L}-$ ornithine $(261 \mathrm{mCi} / \mathrm{mmol})$ and $\left[\mathrm{U}^{14} \mathrm{C}\right]-\mathrm{L}$-proline $(294 \mathrm{mCi} /$ $\mathrm{mmol})$ were supplied by New England Nuclear.

\section{RESULTS AND DISCUSSION}

1. Formation of ammonia (not urea) in the first step of arginine catabolism

The results concerning arginine metabolism reported up to now ${ }^{1 \sim 6)}$ permit the presumption that urea may be produced from arginine by starved ciliates (bacteria-free) and accumulated in the medium, since the starved ciliates have no ureolytic activity and may have arginase activity. ${ }^{2)}$ Thus in the first experiment, formation of urea and/or ammonia from arginine and also from citrulline, ornithine, proline, lysine, histidine, aspartate, asparagine, glutamate, glutamine and urea were examined using a starved $(24 \mathrm{hr})$ ciliate suspension in the presence of three kinds of antibiotics. The results (Table I) revealed that urea was never

Table I. Production of Urea and Ammonia from SOME Amino Acids or Urea by Starved Rumen Ciliates

Incubation time, $6 \mathrm{hr}$.

\begin{tabular}{ccc}
\hline $\begin{array}{c}\text { Substrates } \\
\text { added }^{a}\end{array}$ & $\begin{array}{c}\text { Urea detected } \\
(\mu \mathrm{mol} / \mathrm{ml})\end{array}$ & $\begin{array}{c}\text { Ammonia produced } \\
(\mu \mathrm{mol} / \mathrm{ml})\end{array}$ \\
\hline Arg & 0 & $1.6 \pm 0.6$ \\
Cit & 0 & $2.0 \pm 1.0$ \\
Orn & 0 & $0.6 \pm 0.3$ \\
Pro & 0 & 0 \\
Lys & 0 & 0 \\
His & 0 & 0 \\
Asp & 0 & 0 \\
Asn & 0 & $1.6 \pm 0.4$ \\
Glu & 0 & 0 \\
Gln & 0 & $4.9 \pm 1.3$ \\
Urea & 9.7 & 0 \\
\hline
\end{tabular}

a The amount of substrate added: Asp, $5 \mu \mathrm{mol} / \mathrm{ml}$; and other amino acids and urea, $10 \mu \mathrm{mol} / \mathrm{ml}$.

$b$ Cit: Citrulline.

Values were calculated as differences between the values with and without substrates and are expressed as means of 10 assays with standard deviations. produced from arginine nor from other amino acids tested, instead ammonia was produced from arginine, citrulline, ornithine, asparagine and glutamine under these experimental conditions, while urea added remained unchanged in the medium in agreement with the result of a previous study. ${ }^{6)}$ Clarke and Hungate ${ }^{12)}$ described that urea was probably the main nitrogenous excretion product in rumen ciliate genera Isotricha and Dasytricha. The present results obtained with starved mixed rumen ciliates, however, did not support their idea. The findings that not urea but ammonia was produced from arginine by the starved rumen ciliates which were ascertained at the same time to have no ureolytic activity and that citrulline was also decomposed to give ammonia cast some doubt on the previous result that ornithine was the first intermediate in arginine catabolism in rumen ciliates. ${ }^{2)}$

\section{Formation of citrulline (not ornithine) in the first step of arginine catabolism}

Degradation of arginine and formation of citrulline, ornithine, proline and $\delta$-aminovalerate (DAV) in the starved ciliate suspension were then quantitatively examined using an amino acid autoanalyzer. As shown in Fig. 1, about $1 \mu \mathrm{mol} / \mathrm{ml}$ of arginine was degraded during the 12-hr incubation period and citrulline clearly appeared in the medium and increased with incubation time as well as ornithine and proline. But there was no increase in DAV. The sum of the concentrations of these three metabolites was almost equivalent

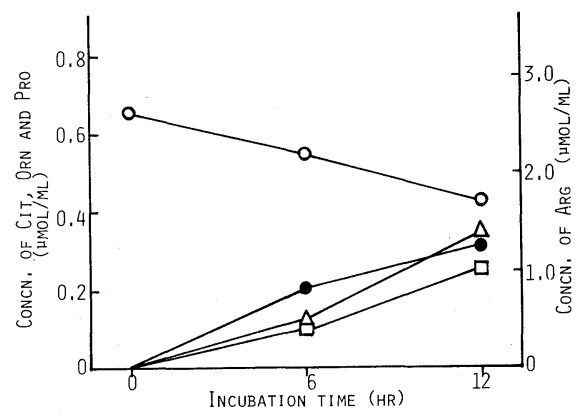

FIG. 1. Time Courses of Arginine Degradation $(\bigcirc)$ and Formation of Citrulline $(\triangle)$, ornithine $(\square)$ and Proline (C) in the Incubation Medium of Starved Rumen Ciliates. 
to the difference between the concentrations of arginine before and after incubation for every incubation time.

Incubation of the starved ciliates with radioactive arginine provided clear evidence that citrulline was surely derived from arginine, as $59.6 \%$ of the initial radioactivity was found in citrulline (Table II). In addition, ornithine, proline and a small amount of DAV were also shown to be produced from arginine. Addition of non-labeled citrulline $(1 \mu \mathrm{mol} / \mathrm{ml})$ to the medium containing radioactive arginine prior to incubation increased the radioactivity in citrulline $(70.1 \%)$ by $c a .10 \%$ and decreased that in proline $(16.0 \%)$ by $c a .8 \%$ after incubation as compared with those in the medium containing only arginine (Table II).

Addition of ornithine $(1 \mu \mathrm{mol} / \mathrm{ml})$ to the incubation medium containing radioactive arginine prior to incubation increased the radioactivity in ornithine and decreased that in proline after incubation as compared with those in the medium containing only arginine (Table II). When L-citrulline was incubated in the starved ciliate suspension, concentrations of ornithine and proline in the medium markedly increased with incubation time, while citrulline inversely decreased (Fig. 2). Thus ornithine seemed to be produced from citrulline. The results in Fig. 2 show that a small amount of arginine increased in the medium in the presence of citrulline.

Ciliates also retained small amounts of radioactivity, but the kinds of radioactive compounds were not identified though arginine and proline might have been there

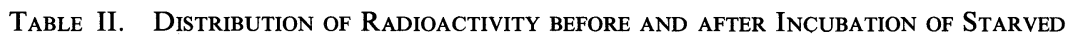
OR Washed Ciliates With [U- ${ }^{14} \mathrm{C}$-L-ARginine $(0.8 \mu \mathrm{Ci} / \mathrm{ml})$ AND NoNLABELED L-ARGININE $(1 \mu \mathrm{mol} / \mathrm{ml})$ AND WITH OR WITHOUT NON-LABELED L-Citrulline OR L-ORNITHINE $(1 \mu \mathrm{mol} / \mathrm{ml})$

\begin{tabular}{|c|c|c|c|c|c|c|c|c|c|c|}
\hline \multirow{4}{*}{$\begin{array}{l}\text { Incubation time, } \mathrm{hr} \\
\text { Fractions }\end{array}$} & \multirow{3}{*}{\multicolumn{2}{|c|}{$\frac{0}{\text { Starved ciliates }}$}} & \multicolumn{8}{|c|}{12} \\
\hline & & & \multicolumn{6}{|c|}{ Starved ciliates } & \multirow{2}{*}{\multicolumn{2}{|c|}{$\begin{array}{c}\text { Washed ciliates } \\
\text { Arg only }\end{array}$}} \\
\hline & & & \multicolumn{2}{|c|}{ Arg only } & \multicolumn{2}{|c|}{$\mathrm{Arg}+\mathrm{Cit}^{*}$} & \multicolumn{2}{|c|}{ Arg + Orn } & & \\
\hline & $\mathrm{nCi} / \mathrm{ml}$ & $(\%)$ & $\mathrm{nCi} / \mathrm{ml}$ & $(\%)$ & $\mathrm{nCi} / \mathrm{ml}$ & $(\%)$ & $\mathrm{nCi} / \mathrm{ml}$ & $(\%)$ & $\mathrm{nCi} / \mathrm{ml}$ & $(\%)$ \\
\hline $\begin{array}{l}\text { Initial radioactivity } \\
\text { Supernatant fluid }\end{array}$ & 800.1 & $(100.0)$ & 721.4 & $(100.0)$ & 789.1 & $(100.0)$ & 757.8 & $(100.0)$ & 815.5 & $(100.0)$ \\
\hline Carbon dioxide & 0 & $(0)$ & 28.2 & $(3.9)$ & 23.0 & $(2.0)$ & 9.9 & $(1.3)$ & .20 .3 & $(2.5)$ \\
\hline Ether extracts & 32.1 & $(4.0)$ & 31.2 & $(4.3)$ & 32.0 & (4.1) & 36.5 & (4.8) & 35.5 & (4.3) \\
\hline Arg & 758.6 & $(94.8)$ & 20.1 & $(2.8)$ & 17.5 & $(2.2)$ & 19.3 & $(2.5)$ & 354.5 & $(43.5)$ \\
\hline $\mathrm{Cit}^{a}$ & 1.9 & $(0.2)$ & 430.1 & $(59.6)$ & 553.5 & $(70.1)$ & 410.4 & $(54.2)$ & 169.9 & $(20.8)$ \\
\hline Orn & 1.9 & $(0.2)$ & 29.0 & $(4.0)$ & 26.5 & (3.4) & 119.9 & $(15.8)$ & 56.8 & $(7.0)$ \\
\hline Pro & 0.5 & $(0.1)$ & 171.2 & $(23.7)$ & 126.3 & $(16.0)$ & 148.5 & (19.6) & 104.7 & $(12.8)$ \\
\hline $\mathrm{DAV}^{b}$ & 2.1 & $(0.3)$ & 5.9 & $(0.8)$ & 5.0 & $(0.6)$ & 8.1 & $(1.1)$ & 29.6 & (3.6) \\
\hline Ciliate hydrolysate & 0 & $(0)$ & 1.0 & $(0.1)$ & 0.9 & $(0.1)$ & 0.8 & $(0.1)$ & 22.4 & $(2.7)$ \\
\hline \multicolumn{11}{|c|}{$\begin{array}{l}a \text { Cit, citrulline. } \\
\text { bAV, } \delta \text {-aminovalerate. } \\
\text { Ciliate nitrogen: starved ciliates, } 0.52 \mathrm{mgN} / \mathrm{ml} \text {; Washed ciliates, } 0.68 \mathrm{mgN} / \mathrm{ml}\end{array}$} \\
\hline & \multicolumn{8}{|c|}{ Composition of ciliates in these expts. } & & \\
\hline & \multicolumn{2}{|c|}{ Entodiniinae } & \multicolumn{2}{|c|}{ Diplodiniinae } & \multicolumn{4}{|c|}{ Isotricha } & & \\
\hline Starved ciliates & \multicolumn{2}{|c|}{1103} & \multicolumn{2}{|l|}{26} & 2 & \multicolumn{3}{|c|}{2} & \multicolumn{2}{|c|}{$\times 10^{3} / \mathrm{ml}$} \\
\hline Washed ciliates & \multicolumn{2}{|c|}{1405} & \multicolumn{2}{|l|}{35} & 2 & \multicolumn{3}{|c|}{0} & \multicolumn{2}{|c|}{$\times 10^{3} / \mathrm{ml}$} \\
\hline
\end{tabular}




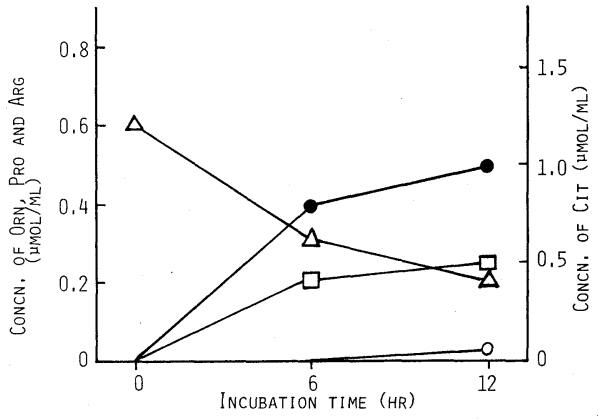

FIG. 2. Time Courses of Citrulline Degradation $(\triangle)$ and Formation of Ornithine ( $\square$ ), Proline (O) and Arginine $(\mathrm{O})$ in the Incubation Medium of Starved Rumen Ciliates.

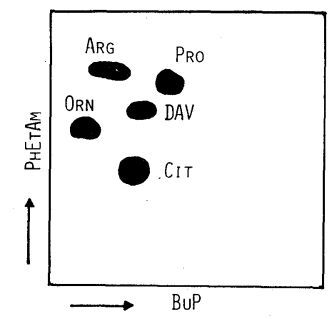

FIG. 3. Autoradiograph of the Two-dimensional Paper Chromatogram of Arginine, Citrulline (Cit), Ornithine, Proline and $\delta$-Aminovalerate (DAV) Developed with Solvents (1) BuP and (2) PhEtAm (see 'Analytical methods').

\section{(Table II).}

By the way, the autoradiograph of the twodimensional paper chromatogram of the supernatant fluid of the incubation medium, which was developed with solvents (1) Bup and (2) PhEtAm (see 'Analytical methods'), showed the clearly separate radioactive spot of citrulline as well as those of arginine, ornithine, proline and a trace of DAV (Fig. 3). In the earlier experiment, ${ }^{2)}$ two-dimensional paper chromatography used for separating amino acids related to arginine metabolism was carried out with solvents (1) $n-\mathrm{BuOH}-\mathrm{AcOH}-$ $\mathrm{H}_{2} \mathrm{O}(4: 1: 2)$ and (2) EtOH- $\mathrm{H}_{2} \mathrm{O}-\mathrm{NH}_{4} \mathrm{OH}$ $(18: 1: 1)$, with which the spots of arginine and citrulline were revealed in the present experiment to be incompletely separated from each other, and the metabolic pathway of arginine speculated at that time was based on only the results of the paper chromatography.

Incubation of a washed ciliate suspension

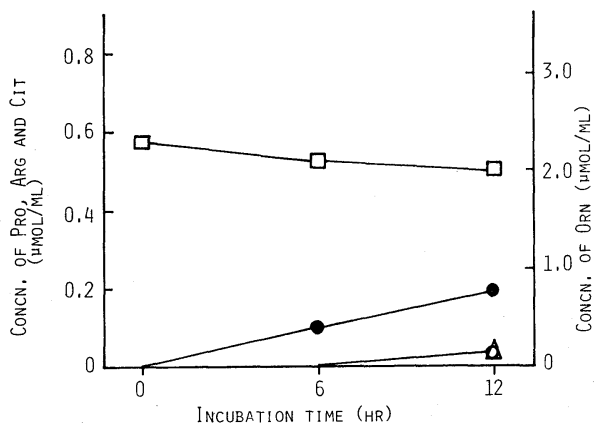

FIG. 4. Time Courses of Ornithine Degradation ( $\square$ ) and Formation of Proline ( () , Citrulline $(\triangle)$ and Arginine $(\bigcirc)$ in the Incubation Medium of Starved Rumen Ciliates.

with radioactive arginine, re-examined in this experiment, clearly revealed the formation of citrulline in addition to ornithine, proline, DAV and carbon dioxide as well as the case of the starved ciliate suspension (Table II). With the washed ciliates, the decomposition of arginine was not to a marked extent, while the formation of DAV was to a marked extent as compared with the case of the starved ciliates (Table II). The incorporation of radioactivity into the ciliate hydrolysate was also remarkable $(2.7 \%$ of the initial radioactivity) and the radioactive components in it were shown to be arginine $(65 \%)$ and proline $(35 \%)$.

All these results led us to the conclusion that citrulline was produced as the first intermediate in arginine catabolism in the rumen ciliate protozoa as well as in that in the mixed rumen bacteria. ${ }^{1)}$ Accordingly, the word 'arginase activity' used in the earlier report ${ }^{6}$ ) should be changed to 'arginine-decomposing activity'

\section{Ornithine metabolism}

L-Ornithine added to the starved ciliate suspension decreased linearly with incubation time and at the same time proline and small amounts of arginine and citrulline increased (Fig. 4). But there was no increase in DAV, different from the results with the washed ciliate suspension. ${ }^{2)}$ Similar results were obtained for the experiment with radioactive ornithine shown in Table III. Formation of 
TABLE III. Distribution OF RADIOACTIVITY BEFORE AND AFTER INCUBATION OF STARVED Ciliates With [U- ${ }^{14} \mathrm{C}$ ]-L-Ornithine $(0.1 \mu \mathrm{Ci} / \mathrm{ml}$ in Expt. I AND $0.7 \mu \mathrm{Ci} / \mathrm{ml}$ IN EXPT. II) AND NON-LABELED L-ORNITHINE $(0.5 \mu \mathrm{mol} / \mathrm{ml})$ AND WITH OR Without NON-LABELED L-PROLINE $(1 \mu \mathrm{mol} / \mathrm{ml})$ OR UREA $(0.5 \mu \mathrm{mol} / \mathrm{ml})$

\begin{tabular}{|c|c|c|c|c|c|c|c|c|c|c|}
\hline \multirow{4}{*}{$\begin{array}{l}\text { Experiments } \\
\text { Incubation time } \\
\text { Fractions }\end{array}$} & \multicolumn{6}{|c|}{ Expt. I } & \multicolumn{4}{|c|}{ Expt. II } \\
\hline & \multirow{2}{*}{\multicolumn{2}{|c|}{$\begin{array}{c}0 \mathrm{hr} \\
\text { Orn only }\end{array}$}} & \multicolumn{4}{|c|}{$12 \mathrm{hr}$} & \multirow{2}{*}{\multicolumn{2}{|c|}{$\frac{0 \mathrm{hr}}{\text { Orn + Urea }}$}} & \multirow{2}{*}{\multicolumn{2}{|c|}{$\frac{12 \mathrm{hr}}{\text { Orn + Urea }}$}} \\
\hline & & & \multicolumn{2}{|c|}{ Orn only } & \multicolumn{2}{|c|}{ Orn + Pro } & & & & \\
\hline & $\mathrm{nCi} / \mathrm{ml}$ & $(\%)$ & $\mathrm{nCi} / \mathrm{ml}$ & $(\%)$ & $\mathrm{nCi} / \mathrm{ml}$ & $(\%)$ & $\mathrm{nCi} / \mathrm{ml}$ & $(\%)$ & $\mathrm{nCi} / \mathrm{ml}$ & $(\%)$ \\
\hline $\begin{array}{l}\text { Initial radioactivity } \\
\text { Supernatant fluid }\end{array}$ & 93.1 & $(100.0)$ & 97.1 & $(100.0)$ & 94.1 & $(100.0)$ & 730.0 & $(100.0)$ & 734.2 & $(100.0)$ \\
\hline Carbon dioxide & 0 & (0) & 0 & (0) & 0 & (0) & 0 & (0) & 0 & (0) \\
\hline Ether extracts & 2.8 & $(3.0)$ & 2.3 & (2.4) & 2.6 & $(2.8)$ & 27.6 & (3.7) & 27.9 & (3.8) \\
\hline Arg & 0.8 & $(0.9)$ & 5.1 & (5.3) & 3.4 & (3.6) & 3.8 & $(0.5)$ & 3.4 & $(0.5)$ \\
\hline $\mathrm{Cit}^{a}$ & 0.2 & $(0.2)$ & 5.6 & $(5.8)$ & 3.9 & (4.1) & 0.7 & $(0.1)$ & 23.1 & (3.1) \\
\hline Orn & 86.2 & (92.6) & 16.3 & $(17.2)$ & 4.9 & $(5.2)$ & 698.0 & (95.6) & 20.4 & $(2.8)$ \\
\hline Pro & 0.3 & $(0.3)$ & 66.7 & (68.7) & 77.5 & (82.4) & 1.7 & $(0.2)$ & 647.3 & $(88.2)$ \\
\hline $\mathrm{DAV}^{b}$ & 0.8 & $(0.9)$ & 1.3 & $(1.3)$ & 1.4 & $(1.5)$ & 5.4 & $(0.7)$ & 8.0 & $(1.1)$ \\
\hline Ciliate hydrolysate & 0 & $(0)$ & 0.3 & $(0.3)$ & 0.2 & $(0.2)$ & 0 & (0) & 2.5 & $(0.3)$ \\
\hline
\end{tabular}

a Cit, citrulline.

$b$ DAV, $\delta$-aminovalerate.

Ciliate nitrogen: Expt. I, $0.22 \mathrm{mgN} / \mathrm{ml}$; Expt. II, $0.51 \mathrm{mgN} / \mathrm{ml}$.

\begin{tabular}{ccccc}
\hline \multicolumn{4}{c}{ Composition of ciliates in these expts. } \\
\cline { 2 - 5 } & Entodiniinae & Diplodiniinae & Dasytricha & \\
\hline Expt. I & 368 & 10 & 0 & $\times 10^{3} / \mathrm{ml}$ \\
Expt. II & 978 & 40 & 4 & $\times 10^{3} / \mathrm{ml}$ \\
\hline
\end{tabular}

proline from radioactive ornithine was also shown in agreement with the previous result. ${ }^{2)}$ In the medium containing only radioactive and non-radioactive ornithine in experiment $I$ in Table III, $17.2 \%$ of the initial radioactivity remained in ornithine after incubation for $12 \mathrm{hr}$, whereas in the medium containing proline in addition to ornithine, only $5.2 \%$ remained. Addition of proline might stimulate the degradation of ornithine. Production of DAV was depressed here compared with that with washed ciliates in Table II. Carbon dioxide and ether-soluble substances were not produced from ornithine by the starved ciliates.

\section{Synthesis of arginine and citrulline}

In the experiment with radioactive orni- thine, radioactivities were apparently detected in the fractions of arginine and citrulline in the supernatant fluid of the medium after incubation (Table III, Exp. I). Addition of urea to the medium containing ornithine resulted in a decrease in the radioactivity in arginine and in no increase in the radioactivity in citrulline (Table III, Exp. II). Urea might inhibit the formation of arginine from citrulline. According to these results and those shown in Figs. 2 and 4, it is possible that rumen ciliates can synthesize citrulline from ornithine and arginine from citrulline required for the synthesis of their own protein.

\section{Formation of DAV from proline}

Incubation of $\left[\mathrm{U}-{ }^{14} \mathrm{C}\right]-\mathrm{L}-$ proline with a starved ciliate suspension hardly involved the for- 
TABLE IV. Distribution OF RADIOACTIVITY BEFORE AND AFTER INCUBATION OF WASHED OR Starved Ciliates With [U-1 $\left.{ }^{14} \mathrm{C}\right]$-L-Proline $(0.9 \mu \mathrm{Ci} / \mathrm{ml})$ AND NoN-LABELED L-Proline $(0.5 \mu \mathrm{mol} / \mathrm{ml})$

\begin{tabular}{|c|c|c|c|c|c|c|}
\hline \multirow{3}{*}{$\begin{array}{l}\text { Incubation time } \\
\text { Fractions }\end{array}$} & \multirow{2}{*}{\multicolumn{2}{|c|}{$\frac{0 \mathrm{hr}}{\text { Washed ciliates }}$}} & \multicolumn{4}{|c|}{$12 \mathrm{hr}$} \\
\hline & & & \multicolumn{2}{|c|}{ Washed ciliates } & \multicolumn{2}{|c|}{ Starved ciliates } \\
\hline & $\mathrm{nCi} / \mathrm{ml}$ & $(\%)$ & $\mathrm{nCi} / \mathrm{ml}$ & $(\%)$ & $\mathrm{nCi} / \mathrm{ml}$ & $(\%)$ \\
\hline $\begin{array}{l}\text { Initial radioactivity } \\
\text { Supernatant fluid }\end{array}$ & 864.7 & $(100.0)$ & 880.1 & $(100.0)$ & 881.7 & $(100.0)$ \\
\hline Carbon dioxide & 0 & (0) & 0 & (0) & 0 & $(0)$ \\
\hline Ether extracts & 37.0 & (4.3) & 39.0 & (4.4) & 38.0 & (4.3) \\
\hline Pro & 821.0 & $(94.9)$ & 632.3 & $(71.8)$ & 837.6 & $(95.0)$ \\
\hline $\mathrm{DAV}^{a}$ & 4.0 & $(0.5)$ & 188.0 & (21.4) & 4.1 & $(0.5)$ \\
\hline Ciliate hydrolysate & 0 & (0) & 14.0 & $(1.6)$ & 8.7 & (1.0) \\
\hline
\end{tabular}

a DAV, $\delta$-aminovalerate.

Ciliate nitrogen: washed ciliates, $0.55 \mathrm{mgN} / \mathrm{ml}$; starved ciliates, $0.5 \mathrm{mgN} / \mathrm{ml}$.

\begin{tabular}{lccccc}
\hline & \multicolumn{5}{c}{ Composition of ciliates in these expts. } \\
\cline { 2 - 5 } & Entodiniinae & Diplodiniinae & Dasytricha & Isotricha \\
\hline Washed ciliates & 1222 & 64 & 8 & 10 & $\times 10^{3} / \mathrm{ml}$ \\
Starved ciliates & 1028 & 14 & 8 & 2 & $\times 10^{3} / \mathrm{ml}$ \\
\hline
\end{tabular}

TABle V. Distribution of Radioactivity BEFore AND AFter INCUBATION OF Rumen Bacterial Suspension CONTAining [U- ${ }^{14} \mathrm{C}$ ]-L-Proline $(0.2 \mu \mathrm{Ci} / \mathrm{ml})$ aND Non-labeled L-Proline $(0.1 \mu \mathrm{mol} / \mathrm{ml})$ WiTh OR Without ANTiBIOTICs ${ }^{a}$

\begin{tabular}{|c|c|c|c|c|c|c|}
\hline \multirow{3}{*}{$\begin{array}{l}\text { Incubation time } \\
\text { Fractions }\end{array}$} & \multicolumn{2}{|c|}{$0 \mathrm{hr}$} & \multicolumn{4}{|c|}{$12 \mathrm{hr}$} \\
\hline & \multicolumn{2}{|c|}{ With antibiotics } & \multicolumn{2}{|c|}{ With antibiotics } & \multicolumn{2}{|c|}{ Without antibiotics } \\
\hline & $\mathrm{nCi} / \mathrm{ml}$ & $(\%)$ & $\mathrm{nCi} / \mathrm{ml}$ & $(\%)$ & $\mathrm{nCi} / \mathrm{ml}$ & $(\%)$ \\
\hline $\begin{array}{l}\text { Initial radioactivity } \\
\text { Supernatant fluid }\end{array}$ & 201.3 & $(100.0)$ & 196.7 & $(100.0)$ & 202.7 & $(100.0)$ \\
\hline Carbon dioxide & 0 & $(0)$ & 0 & $(0)$ & 64.6 & (31.9) \\
\hline Ether extracts & 14.9 & $(7.4)$ & 15.0 & $(7.6)$ & 15.7 & $(7.7)$ \\
\hline Pro & 182.8 & $(90.8)$ & 173.5 & $(88.2)$ & 9.0 & (4.4) \\
\hline $\mathrm{DAV}^{b}$ & 0.8 & $(0.4)$ & 0.8 & $(0.4)$ & 0.4 & $(0.2)$ \\
\hline
\end{tabular}

a Antibiotics used: $100 \mu \mathrm{g} / \mathrm{ml}$ each of dihydrostreptomycin sulfate, penicilline $\mathrm{G}$ potassium and chloramphenicol sodium succinate.

${ }^{b} \quad \mathrm{DAV}, \delta$-aminovalerate.

mation of DAV (Table IV), different from the result with the washed ciliate suspension. ${ }^{2)}$ The result obtained with a washed ciliate suspension in the present experiment again showed the remarkable formation of DAV (Table IV). In order to determine the participation of mingled bacteria in the formation of DAV, a rumen bacterial suspension prepared from washings of rumen ciliates was incubated with radioactive proline for $12 \mathrm{hr}$ in the presence or absence of three kinds of antibiotics. As shown in Table $\mathrm{V}$, radioactive proline remained unchanged in the rumen bacterial suspension in the presence of the antibiotics, but it was 


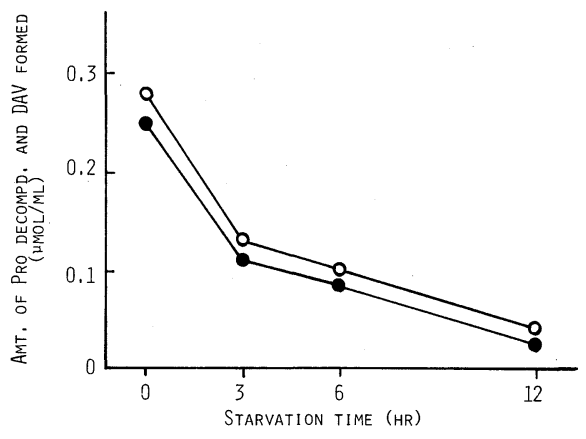

FIG. 5. Effect of Starvation Time of Rumen Ciliates on the Degradation of Proline $(O)$ and Formation of $\delta$ Aminovalerate (DAV) (O).

Each starved ciliate suspension was incubated with [U$\left.{ }^{14} \mathrm{C}\right]$-L-proline $(0.8 \mu \mathrm{Ci} / \mathrm{ml})$ and non-labeled proline $(0.5 \mu \mathrm{mol} / \mathrm{ml})$ for $12 \mathrm{hr}$ and the results are expressed as $\mu \mathrm{mol} / \mathrm{ml}$ of proline degraded and DAV formed.

decomposed to give solely radioactive carbon dioxide in the absence of the antibiotics. Thus the formation of DAV from proline in the washed ciliate suspension containing the antibiotics was attributed not to the mingled bacteria but to the ciliates themselves. The fact that there was no production of carbon dioxide in the washed ciliate suspension after incubation (Table IV) also supported this conclusion.

As demonstrated previously, ${ }^{2)}$ DAV underwent no more decomposition in the rumen ciliate suspension, different from the result for the mixed rumen bacterial suspension. ${ }^{1)}$

Then the relationship between the ability for ciliates to reduce proline to DAV and the incubation period required for preparing the starved ciliates was examined and the results are shown in Fig. 5. Prolongation of the incubation time resulted in an apparent reduction in the ability of rumen ciliates to produce DAV from proline. Additional research is needed to clarify the reasons why the ability is reduced.

\section{General conclusion}

All the results obtained in these experiments might lead one to the following conclusions.

In the first step of arginine catabolism in the mixed rumen ciliate suspension, ammonia but not urea and citrulline but not ornithine were produced. Citrulline produced from arginine seemed to be in turn converted to ornithine with the production of ammonia and carbon dioxide. Subsequently ornithine was converted to proline with the formation of ammonia, proline then being reduced to DAV which seemed to be the end product in arginine catabolism of the mixed rumen ciliate protozoa.

It is of special interest that the possibility of rumen ciliate protozoa synthesizing arginine was suggested.

Acknowledgments. The authors are grateful to Dr. $\mathrm{H}$. Ogawa, Miyazaki University, for inserting the permanent fistula into the goat rumen. This work was •partially supported by the Radioisotope Center, Miyazaki University.

\section{REFERENCES}

1) C. Van den Hende, W. Oyaert and J. H. Bouchaert, Res. Vet. Sci., 5, 491 (1964).

2) R. Onodera, W. Tsutsumi and M. Kandatsu, Agric. Biol. Chem., 41, 2169 (1977).

3) A. R. Abou Akkada and B. H. Howard, Biochem. J., 82, 313 (1962).

4) M. Kandatsu and N. Takahashi, Nippon Nôgeikagaku Kaishi, 37, 486 (1963).

5) M. A. Naga and K. El-Shazly, J. Gen. Microbiol., 53, 305 (1968).

6) R. Onodera, Y. Nakagawa and M. Kandatsu, Agric. Biol. Chem., 41, 2177 (1977).

7) R. Onodera, H. Yamaguchi, C. Eguchi and $M$. Kandatsu, Agric. Biol. Chem., 41, 2465 (1977).

8) W. Tsutsumi, R. Onodera and M. Kandatsu, Agric. Biol. Chem., 39, 711 (1975).

9) R. Onodera and C. Henderson, J. Appl. Bacteriol., 48, 125 (1980).

10) D. D. Van Slyke, R. T. Dillon, D. A. MacFadyen and P. Hamilton, J. Biol. Chem., 141, 627 (1941).

11) E. J. Conway, "Microdiffusion Analysis and Volumetric Error," Crosby Lockwood and Son Ltd., London, 1950.

12) R. T. J. Clarke and R. E. Hungate, Appl. Microbiol., 14, 340 (1966). 